stems, roots and leaves. During the Middle Devonian period there were leaves of several types which seem to be derived from specialized photosynthetic branches. A variety of large, much divided fronds appears in the Upper Devonian-Lower Carboniferous rocks; their ultimate segments were usually small or narrow. Several of them belonged to seed-bearing plants - the pteridosperms. In Upper CarboniferousLower Permian times this group had more compact fronds, with larger, partly concrescent pinnules; reticulate venation appeared in some genera. Among these, Gigantopteris approaches the type of leaf now characteristic of dicotyledons. Petrified stems with a wide range of structure have been found; some of them suggest an approach to angiospermous structure.

The sequence of reproductive structures forms a coherent series which should be studied without reference to morphological preconceptions. Most of the earlier types had their sporangia on the ends of fertile branches, often in groups. This habit continued through Upper Palæozoic times. Kidston described six different forms of pteridospermous pollen-bearing structures from the Lower Carboniferous, with terminal groups of radially arranged sporangia, and Halle has investigated a number of similar structures from the Upper Carboniferous. All are constructed on the same general plan, which is also seen in the male flowers of many unisexual angiosperms to-day. These structures, as well as the cupulate seeds, generally grew on special branch systems. Halle's suggestion is recalled, that in one line of pteridosperm evolution the plant body was differentiated into a vegetative and a reproductive region, the spore-producing members congregating to form some kind of inflorescence or flower borne directly on branches of the stem and not on leaves. The Triassic pteridosperms from South Africa had dichasial inflorescences and support this view. Another link between the pteridosperms and the angiosperms is provided by certain rare and undescribed fossils from the Molteno beds of South Africa. These show inflorescences of a dichasial type, bearing small flowers with delicate perianth segments.

The closed ovary of the angiosperms may have been derived from the open cupules of the pteridosperms. The Jurassic Caytonia suggests how the closure may have come about, and Prof. Doyle's researches on pollination and fertilization in the conifers are interesting in this connexion.

Traces of flowering plants occur in the Upper Jurassic and increase in number until they form more than 90 per cent of the floras in the Eocene rocks. The widely different types present in Cretaceous beds suggest that the group must have originated in Upper Palæozoic or early Mesozoic times. An investigation of the spore content of freshwater sediments may throw light on this suggestion. A high percentage of the families represented in the Upper CretaceousLower Tertiary floras show primitive characters in their secondary wood ; by statistical analysis, Sporne has been able to discover other characters probably possessed by the more primitive dicotyledons.

All these studies are independent of morphological theory, and since plant morphology has developed as a deductive study they suggest that a reconsideration of its concepts are necessary. The War showed the importance of a complete and objective analysis of information as a basis for action. This is a principle applicable both to the problems which have been here considered, and to all the affairs of national life.

\section{EVOLUTION OF SECONDARY EDUCATION}

TN her presidential address to Section L (Education), Miss Lynda Grier discusses "The Evolution of Secondary Education in Britain". The most notable features in the evolution of secondary education in Britain have been, she said, the growth and constant power of the classical tradition, and its decay; the growth of democracy, including the growth of the woman's movement; the coming of science with a new conception of humanism in education, and the interest in technical education.

The dominance of classics in education in the first instance was due to the fact that they were useful and paved the way to office in Chureh and State, that they were necessary to lawyers and diplo. matists, won favour at court, and were, in brief, the main requisite for any who wished to enter the learned professions. Conservatism kept classical teaching powerful when the direct usefulness of the classics had ceased, and brought about a decline in the number of grammar schools, and in the numbers at the universities, until the latter began to take note of the new learning, and it was slowly recognized that education should have some connexion with the world in which men and women had to live. This recognition was due to the growth of democracy and the increasing need of the sciences for the contribution of learned thought and training. As these things came to the fore, secondary education began slowly to take its rightful place in men's minds as something that should be offered to all children.

Early democratic ideas in education in England, unlike those of Commenius, were selective and concerned with the provision of ladders for the poor and able, which would set them side by side with the rich, or even, as some of the most democratic of early English thinkers suggested, above the rich, if the rich were not worthy of the education offered. Hence the English system was profuse in scholarship provision, generously but definitely selective. Interest in the higher education of women suffered an even greater decline than did that for men, until the gradual emergence of a true democracy.

Mathematics and science were not neglected entirely, for indeed much fine work was done in both. But it was carried on outside the universities and grammar schools; and schools of a different type were set up for their teaching, or else, as suggested by Locke, they were taught by private tutors, until at last the ancient universities began to recognize their importance. Technical education, which should long since have come into an important place in education, given the decay of apprenticeship and the competition of other countries, has only recently established its claims in the provision of secondary education.

The general neglect by the State of secondary education in Britain allowed for great variety in it, since what was done was in the hands of private bodies and individuals with widely different points of view. The recent Education Act and all the interpretations given to it by the Ministry of Education recognize the value of that variety. In achieving for the first time a complete system of education, with secondary education for all, it is recognized that unity is incompatible with uniformity, and that the greater the variety the more perfect can be the result. 